Lubrication in Practice 
Other related titles from Macmillan

J. Halling (Ed.): Principles of Tribology

Alan T. J. Haywood: Flowmeters - a basic guide and source-book for users 


\section{Lubrication in Practice}

Edited by

W S Robertson

Second edition

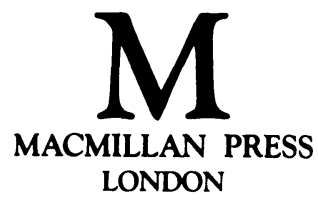

Esso 
(C) Esso Petroleum Company Limited 1972, 1983

Softcover reprint of the hardcover 1st edition 1983 978-0-333-34978-6

All rights reserved. No part of this publication may be reproduced or transmitted, in any form or by any means, without permission.

First edition 1972

Second edition 1983

Published by

THE MACMILLAN PRESS LTD

London and Basingstoke

Companies and representatives

throughout the world

ISBN 978-1-349-06733-6

ISBN 978-1-349-06731-2 (eBook)

DOI 10.1007/978-1-349-06731-2 


\section{Contents}

Preface

1 Theory and basic principles

A. J. S. Baker and R. T. Davies 1

2 Types and properties of lubricants

W. S. Robertson

3 Diesel and petrol engine lubrication

B. N. Seth

4 Lubrication of water and steam turbines

M. G. Hayler and A. C. M. Wilson

5 Industrial gas-turbine lubrication

M. G. Hayler, A. T. Langton and L. F. Rutishauser

6 Lubrication of gears and drives

S. J. Crampton and M. G. Hayler

7 Hydraulic transmissions

A. B. Barr, D. F. G. Hampson and W. Y. Harper

8 Compressor lubrication

D. F. G. Hampson

9 Lubricating machine tools

L. H. Haygreen

10 Mobile plant and agricultural equipment lubrication

A. B. Barr and W. Y. Harper

11 Grease lubrication

E. F. Jones 
12 Cutting oils

A. R. Lindsay and J. C. D. Russell

13 Metal rolling operations

B. A. Cook

14 Planning for all lubrication requirements

M. D. Cox and J. S. Faircloth

15 Lubricant storage and handling

M. D. Cox and M. P. Redgard

Index 


\section{Preface}

Lubrication is important to every student, engineer and manager in industry: to help keep machines or production lines operating, to improve metal-working productivity, and as a vital part of industrial design.

Many books are available that comprehensively cover the theory of lubrication and other aspects of tribology. However, engineers and managers often need to know what lubricants do, and how they can best be used, rather than precisely how they function. That is the approach that Lubrication in Practice has taken. Its authors have all worked, in Esso and in other companies, on a wide range of practical lubrication and lubricant applications.

The first chapter summarises basic lubrication theory but does not attempt to deal with it in any detail. Chapter 2 discusses the types and properties of lubricants. The next eleven chapters cover such specific applications as diesel and petrol engines, hydraulics, compressors, machine tools and cutting oils. The final two chapters are on the storage and handling of lubricants, and on lubrication planning.

The information in Lubrication in Practice is designed to help people in industry increase overall efficiency and save money by improving lubrication practices. However, this information is necessarily general in scope and cannot cover all circumstances. It is therefore always desirable to take specific advice, whether from consultants, specialists or qualified lubricant suppliers, in applying this information to individual cases.

The second edition of this book has been completely updated in the light of developments since the first edition was published in 1972. This edition is being published in the centenary year of Beauchamp Tower's first report to the Institution of Mechanical Engineers on the Friction of Lubricated Bearings. Wider knowledge of the practical implications of such studies is quite as important now as it was then.

The potential financial benefits are much more important now. Nearly 20 years ago, in 1966, the Jost Report said that Britain could save $£ 500$ million a year by better tribological practices, including improved lubrication. That saving is equivalent to at least $£ 2000$ million a year today.

Lubrication in Practice is designed to give its readers some practical assistance in their efforts to achieve, within their own organisations, some share of that potential saving. 